\title{
Climate models fail to 'predict' US droughts
}

Simulations identify past megadroughts, but at wrong times.

\section{BY QUIRIN SCHIERMEIER}

C 7 his would be a fine country if it only had water," observes a settler looking at the barren west Texas plains. "So would Hell," replies a despairing farmer.

That old Texas joke probably originated in the 1950s, when the state was baked by its most relentless drought in recorded history. Last year, rain kept clear of the region again, and scientists predict that the entire North American southwest will become increasingly droughtprone as climate change proceeds ${ }^{1}$.

Reliable forecasts of future 'megadroughts' would be a boon to farmers and water managers. But results presented last week at the annual assembly of the European Geosciences Union in Vienna suggest that such forecasts are still beyond the reach of current climate models.

Sloan Coats of Columbia University's Lamont-Doherty Earth Observatory in Palisades, New York, and his colleagues tested whether a state-of-the-art climate model could simulate the droughts known to have occurred in the southwest during the past millennium. The model incorporated realistic numbers for factors that affect temperature and rainfall, such as atmospheric carbon dioxide levels, changes in solar radiation and ash from volcanic eruptions.

It also incorporated changes in the El Niño/ Southern Oscillation (ENSO), a recurring temperature anomaly in the tropical Pacific that greatly affects weather in the western United States and many other parts of the world. (The warm phase - El Niño - often brings torrential rain and flooding; the cold phase La Niña — tends to bring drought.) The team then compared the results of its simulations with data from the North American Drought Atlas, a detailed compilation of droughts based on the thickness of tree rings.

The results were puzzling. Although the simulation produced a number of pronounced droughts lasting several decades each, these did not match the timing of known megadroughts. In fact, drought occurrences were no more in agreement when the model was fed realistic values for variables that influence rainfall than when it ran control simulations in which the values were unrealistically held constant. "The model seems to miss some of the dynamics that drive large droughts," says study participant Jason Smerdon, a researcher at LamontDoherty who studies historical climate patterns.

Other climate models tested by the team fared no better, he says. In particular, the models failed to reproduce a series of multi-decadal droughts that occurred in the southwest during the Medieval Climate Anomaly, a period between AD 900 and 1200 when global temperatures were about as high as they are today.

The problem may lie in the models' inability to reproduce the cycling between the ENSO's El Niño and La Niña phases, especially given that many scientists think that La Niña is the major driver of drought in the southwest. The ENSO "behaves much messier in the real world than in climate models", says Jessica Tierney, a climate scientist at the Woods Hole Oceanographic Institution in Massachusetts who has investigated the role of the ENSO in East African rainfall variability ${ }^{2}$. "We're not sure how it

"The model seems to miss some of the dynamics that drive large droughts." failure to reproduce El Niño and La Niña, existing models do not fully capture other factors that influence rainfall, such as clouds and vegetation. But Smerdon adds that the atmospheric and oceanic dynamics that inhibit rainfall and favour prolonged drought may be essentially random and so almost unpredictable.

Last week's findings highlight the broader challenge of predicting how precipitation patterns will change as the global climate warms. Models are often at odds over the very direction of regional changes. For example, different projections prepared for the Colorado Water Conservation Board disagree on whether mean precipitation in the state will increase or decrease by 2050 (ref. 3).

But the uncertainties don't change the larger picture, scientists say. "Climate models are not perfect, but they do the big things really well," says Tierney. "We can be pretty confident that the southwest will warm and that water will become scarcer." -

1. Seager, R. et al. Science 316, 1181-1884 (2007).

2. Tierney, J. E., Smerdon, J. E., Anchukaitis, K. J. \& Seager, R. Nature 493, 389-392 (2013).

3. Ray, A. J. et al. Climate Change in Colorado: A Synthesis to Support Water Resources Management and Adaptation (Colorado Water Conservation Board, 2008); available at go.nature.com/xs8471. 